\title{
The tectonic evolution of Lake Eğirdir, West Turkey
}

\author{
M. Erkan Karaman \\ Department of Geological Engineering, Akdeniz University, 07058 Campus Antalya, Turkey; \\ e-mail: ekaraman@akdeniz.edu.tr
}

\begin{abstract}
Lake Eğirdir is one of the most important fresh-water lakes of Turkey. It has a tectonics-related origin. The area formed under a roughly N-S compressional tectonic regime during the Middle Miocene. The stresses caused slip faults west and east of Isparta Angle, and the lake formed at the junction of these faults. The area subsided between normal faults, thus creating the topographic condition required for a lake. The lacustrine sediments have fundamentally different lithologies. After the Late Miocene, central Anatolia started to move westwards, but western Anatolia moved in a SW direction along the South-western Anatolian Fault, which we suggest to have a left lateral slip, which caused that the Hoyran Basin moved $t 7 \mathrm{~km}$ towards the SW and rotated $40^{\circ}$ counterclockwise relative to Lake Eğirdir.
\end{abstract}

Keywords: tectonic evolution, Lake Eğirdir, Isparta Angle, rotation, South-western Anatolian Fault, Burdur-Fethiye Fault Zone, Miocene-Pleistocene

\section{Introduction}

Lakes Eğirdir, Beysehir and Burdur are situated where central and western Anatolia meet, in an area known as the lake district (Fig. 1). Lake Eğirdir is one of the largest tectonics-induced lakes of Anatolia, but the environmental (including the depositional) conditions also affected the development of the lake.

The tectonics of the Alpine-Himalayan belt pose several problems. One of them is the Isparta Angle, which is an important tectonic structure in this belt, is located between western and central Anatolia, surrounding Lake Eğirdir in the Taurus belt. The Isparta Angle is formed by the South-western Anatolian Fault and the Kurkavak Fault. Lake Eğirdir is located in the apex of this angle in the North. The directions and velocity of the structural units forming the western and eastern parts of the Isparta Angle are mutually different.

The present contribution is aimed at unravelling the tectonic evolution of Lake Eğirdir, to define the geodynamics of the Isparta Angle, and their interrelationship. The Hoyran Basin and the Kaşıkara graben underwent a $40^{\circ}$ counterclockwise rotation relative to the simultaneously formed Eğirdir-Kovada graben to their south. The rotation resulted from a change from an initially westward movement of Anatolia to - a south-westward movement. The analysis of the regional tectonics around Lake Eğirdir presented here is hoped to add to the understanding of the geodynamic evolution of the Alpine-Taurus-Himalayan seismic belt. An attempt will also be made to elucidate the stages that can be discerned in its geological evolution. 


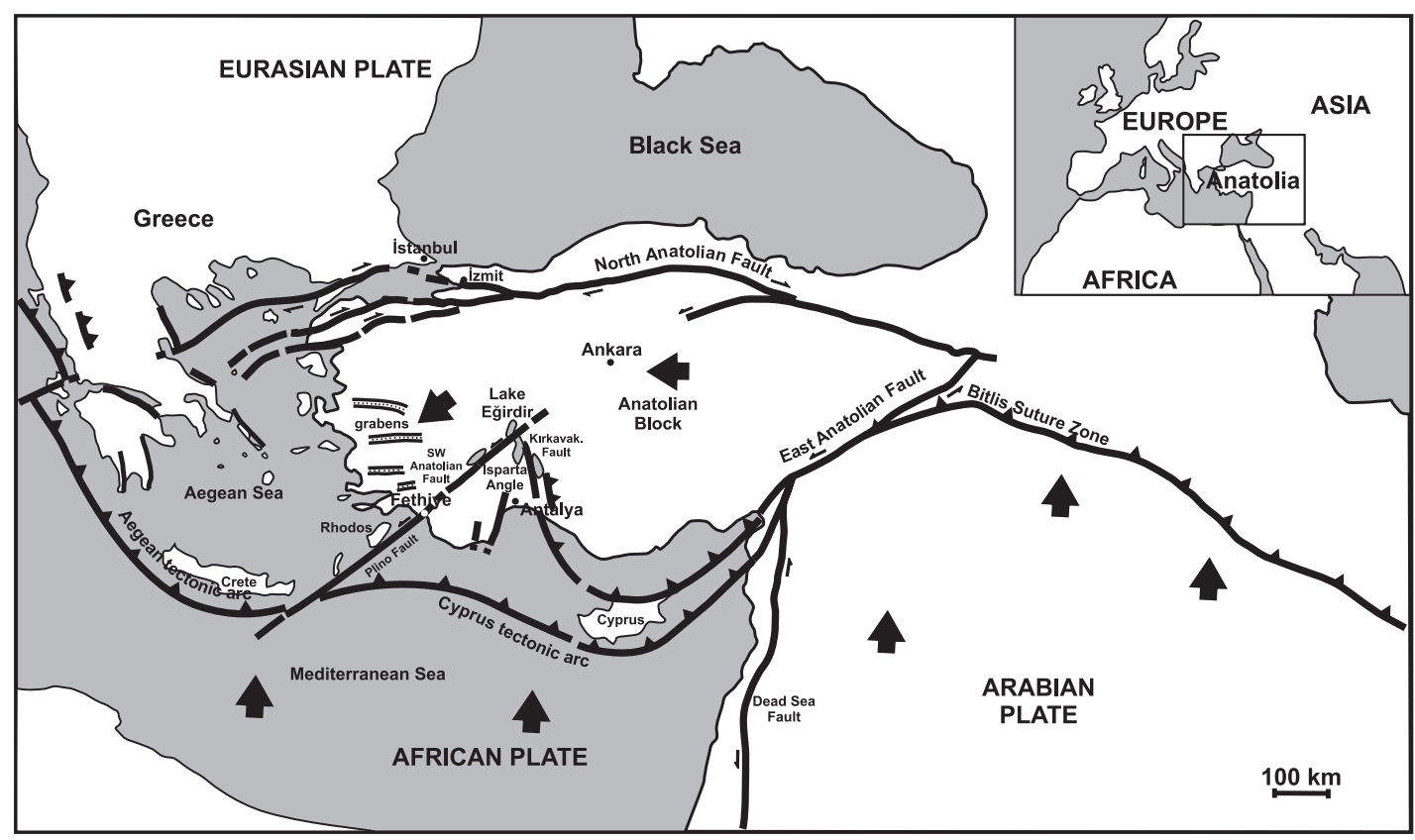

Fig. 1. Location of Lake Eğirdir and overview of the main tectonic lines in Turkey and the Isparta Angle.

\section{Previous researches}

Numerous geological studies have been carried out in the vicinity of Lake Egirdir, but hardly any research was devoted to the development and age of the lake. Most of these studies assigned an age on the basis of non-tectonic data, but it turns out that tectonics, in addition to processes such as erosion and weathering, played a major role.

Some research dealt with the geological and geomorphological development and characteristics of the Lake Egirdir Basin. The first of these studies was completed by Alagöz (1944), who concluded that the Lake Egirdir depression originated from karst during a pluvial phase (Pliocene-Pleistocene), when it also became filled with water. Lahn $(1945,1948)$ suggested that the lake depression has a tectonical origin and that it became filled with water in the last part of the Neogene. Ardel (1951) stated that the lake is due to the collapse of a major polje, and that the small islands within the lake support this interpretation. Inandik (1965) proposed, like Alagöz (1944), that the depression acquired its present shape through karst, and that the lake developed during a pluvial phase. Erol (1969, 1984) evaluated Lake Egirdir and all other major water bodies in the region, on the basis of the palaeoclimate of Anatolia, as pluvial.
The deposits of the lake consist of a single layer of pumice lapilli that is $30 \mathrm{~cm}$ to $1 \mathrm{~m}$ thick. This layer resulted from an eruption that resulted in equivalents deposits $25 \mathrm{~km}$ from the Gölcük volcano which is situated some 25 $\mathrm{km}$ to the West. The eruption is probably related to the growth of the last trachytic domes that have been found (Platevoet et al., 2008). Kazanci (1993) indicated that, south of Lake Egirdir, pyroclastic-fall sediments occur within the successions of alluvial cones that advance toward the lake, and that these pyroclastics are products of the Pliocene Gölcük (Isparta) volcanism, thus implying that the lake basin developed prior to the middle-late Pliocene. Kazanci (1993) also noted that a series of talus cones exist on the flanks of Sivri Tepe, a hill of $1750 \mathrm{~m}$ high near the town of Egirdir, and that these cones are overlapping and juxtaposed, comprising colluvial sediments. He considered the tuff levels within the colluvial sediments to be marker horizons, and suggested that they were derived from the Pliocene Isparta-Gölcük maar, located at least $25 \mathrm{~km}$ away (Kazanci \& Karaman, 1988). Kazanci (1993) suggested in this context that the lake basin formed prior to the middle-late Pliocene. Moreover, he suggested that it was a response to the tectonics that formed the Isparta Flexure and that, later, the lake depression was shaped by karst and 
ultimately filled with water in a pluvial time, as suggested by various other workers. More recently, Kazanci (1995) investigated the development of the lake and carried out radiometric dating of tuffs. These tuffs, sampled west of Egirdir, were dated using the K-Ar method and yielded ages of $1.38 \pm 0.13 \mathrm{Ma}$ and $1.50 \pm 0.18$ Ma for the upper and lower tuffs, respectively; these ages correspond to the Early Pliocene. Thus, the debris slopes on which the Eğirdir colluvium was deposited must have been formed before the middle-late Pliocene.

More research has been carried out on a wide range of geological topics concerning Lake Egirdir and its surroundings (Poisson, 1984; Boray et al., 1985; Yağmurlu \& Karaman, 1987; Karaman, 1988, 1989; Hançer \& Karaman, 1991, 1993, 1994; Yağmurlu, 1991; Kibici et al., 1993; Barka et al., 1995; Poisson et al., 2003; Platevoet et al., 2008).

\section{Geological setting}

Lake Egirdir occupies, together with two other large lakes, a wetland area termed the 'Lake District'. Lake Egirdir is the northernmost lake, and the Burdur and Beysehir Lakes are situated such that they are almost mirror images of one another. The positions of the three lakes have drawn the attention of geoscientists for years and have triggered many investigations. these studies indicate a pre-Pliocene development of the Lake Egirdir Basin, but do not provide definite information its age. However, the initial stage of lake-basin development was shown to be coeval with the onset of the tectonic processes that gave rise to the basin. Therefore, the age of the basin is related to the displacements caused by the South-western Anatolian Fault and the Kurkavak Fault, which took place during the Middle Miocene.

The position of the three lakes is also closely related to the Isparta Flexure (Blumenthal, 1963), or the Isparta Angle (Koçyiğit, 1983). Lake Egirdir is situated at the northern end, whereas Lake Burdur and Lake Beysehir are located at the western and eastern margins of this structure, respectively. The Isparta Angle, in the western Taurus Mountains, is a large tectonic structure with the shape of a triangle, with Lake Egirdir in the north, and Fethiye Bay and Manavgat at its southern corners (Fig. 1); this structure also conforms the geometry of the Gulf of Antalya to the south. The Taurus Mountains have a general E-W orientation but north of the Gulf of Antalya this trend is disrupted, so that a V-shape results (Fig.1).

The area occupied by the Isparta Angle comprises autochthonous and allochthonous rock units of various types and ages. The autochthonous rock units consist mainly of calcareous and siliciclastic marine sediments that were deposited during the Mesozoic and Cenozoic. The allochthonous units form three main groups: (1) the Antalya nappes, which were emplaced in the region between the Cretaceous and Palaeocene, (2) the Beysehir Hoyran nappes, emplaced in the Eocene, and (3) the Lycian nappes, emplaced in the Miocene. Because they are beyond the scope of the present contribution, these units will not be dealt with in any detail here in.

The Isparta Angle comprises three main tectonic elements (Fig.1). These are(1) the Southwestern Anatolian Fault, on the western margin of the Isparta Angle, (2) the Kirkavak Fault, on the eastern margin of the Isparta Angle, and (3) the Aegean-Cyprus tectonic arcs, on the southern margin of the Isparta Angle. The relevant aspects of these structural elements are detailed in the following.

\section{The western margin of the Isparta Angle}

The South-western Anatolian Fault is a strike-slip fault. It constitutes the western margin of the Isparta Angle and is located between Fethiye and Eğirdir. The fault formed towards the end of an older tectonically active stage and continued its development throughout the post-Miocene stage of neotectonics. Before 1988, the fault was known as the Burdur Fault, which was considered to reflect a dipslip movement, and which formed the southeastern side of Lake Burdur. Its main fault plane is vertical or nearly so. In addition, slickensides on the fault plane show a sinistral mo- 
tion, and in some sections dip-slip components occur. Karaman (1988) was the first to consider this fault as a regional fault zone, which view was shared by most geologists only after years. The zone includes, as some examples, the Fethiye Fault, the Fethiye-Burdur Fault, the Çameli-Gölhisar Fault Zone (Şaroğlu, 1992), but also the Fethiye Burdur Fault Zone (Barka et al.,1995; Yağmurlu et al., 2000; Alçiçek et al., 2005; Erdoğan \& Şahin, 2006; Bozcu et al., 2007).

Along the strike of the fault, western Anatolia is moving to the south-west; and E to W (west vergent) subsidence takes place via dipslip components in the fault zone, and grabens and basins are consequently developing. Earthquakes that have occurred in the region over time have been caused by movement along this fault zone.

\section{The eastern margin of the Isparta Angle}

The Kurkavak Fault is a strike-slip fault; it constitutes the eastern margin of the Isparta Angle (Dumont \& Kerey, 1975). This fault forms a roughly N-S trending tectonic boundary between the western Taurus Mountains and the Köprü Çay Basin. It is the first strikeslip fault recognized in the western part of the Taurides. It operated as a strike-slip fault in the Miocene; later, compression occurred along the same direction (Dumont \& Kerey, 1975; Boray et al.,1985; Poisson et al., 2003). According to Dumont \& Kerey (1975), the position of the tectonic features in the field indicates that this fault was a dextral strike-slip fault during the Miocene, but acted as a thrust afterwards.

In the eastern part of the Isparta Angle between Isparta and Serik, the Aksu Fault - which is $50 \mathrm{~km}$ long - has been recognized as a reverse fault system (Poisson et al., 2003). All along the length of this fault system, the Mesozoic limestone/shale units of the western Taurides have been thrusted onto younger Miocene rocks. Many other nearby thrust faults have developed parallel to the Aksu thrust.

\section{The southern margin of the Isparta Angle}

The Aegean-Cyprus tectonic arcs occur at the southern margin of the Isparta Angle. The Aegean Tectonic Arc is located west of the Gulf of Antalya, whereas the Cyprus Tectonic Arc is situated east of it; both arcs have different seismotectonic characteristics: $t$ although frequent earthquakes along both arcs, the Aegean Tectonic Arc has a higher seismicity rather than the Cyprus Tectonic Arc.

The arcs constitute a subduction zone that results from the collision of the African plate with the Eurasian plate, which collision results in one of the two belts worldwide where most earthquakes occur. Along these arcs, the African plate is being subducted northwards beneath the Anatolian plate; this is a classical example of plate boundaries along which oceanic/continental collision occurs. The Anatolian plate is consequently narrowing along an approximately N-S direction, and is - as a result of compression - forced to move westwards along the North Anatolian and East Anatolian faults.

\section{Geological characteristics of the ancient lake basin}

During the first (early Miocene) tectonic phase, some area parts of Western Taurus which are called 'Sultandağlari' and 'Emir Dağları' had become uplifted by tectonics, but some other areas had subsided becoming a basin, such as Akșehir, Eber, Karamık, Beyşehir, Burdur, Hoyran, Kașıkara, Kovada, and Eğirdir (Fig. 2). After the Mio-Pliocene, these tectonic basins became filled, thus becoming lakes.

The surroundings of the present-day Lake Egirdir Basin consist of carbonate rocks such as limestone and dolomitic limestone are present. The area has been the object of numerous geological investigations, which were carried out particularly in the transition zone between the western and eastern Taurides (e.g., Dumont \& Kerey, 1975; Koçyiğit, 1981, 1983; Yağmurlu, 1991). Dumont \& Kerey (1975), in their study south of Lake Egirdir, recognized several units 


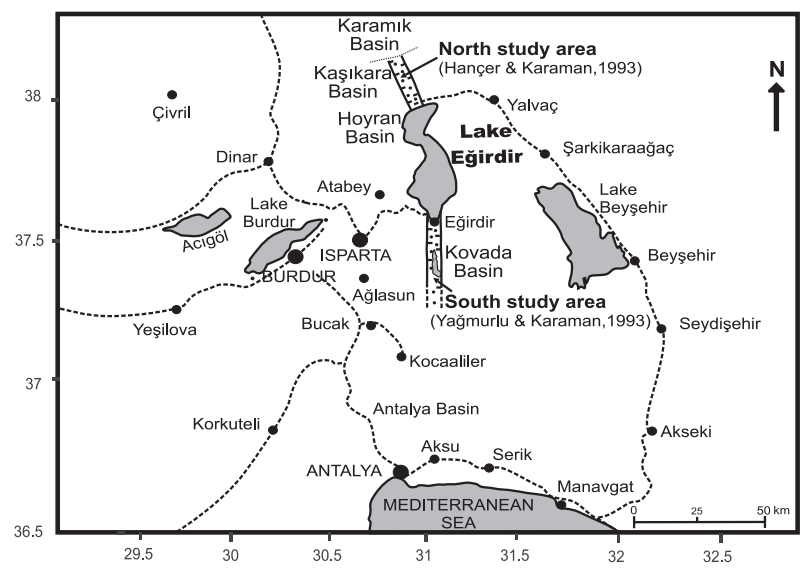

Fig. 2. Location of the graben basins north and east of Lake Eğirdir.

and showed that a significant number of the rocks near the lake belong to the Dulup Unit.

The Neogene Kaşıkara and Kovada Basins of the region are closely related to the lake and contain ancient lacustrine sediments; lacustrine sedimentation still continues within Lake Egirdir. The Kaşıkara Basin is situated north of Lake Egirdir, whereas the Kovada Basin is to the south of the lake; the distance between the northernmost end of the Kaşıkara Basin and the southernmost end of the Kovada Basin is approx. $100 \mathrm{~km}$ (Figs 2, 3). The widths (E-W) of the Kaşıkara and Kovada Basins are roughly the same, between 1.5 and $2 \mathrm{~km}$. r. These basins, as well as the normal faults that bound them, are important for understanding both the formation of Lake Egirdir and the geotectonic evolution of south-western Anatolia.

\section{The Kaşıkara Basin}

Some geological data concerning this Basinhave been obtained by Hançer \& Karaman (1994) and Kibici et al. (1993); these are summarized below. The Kaşıkara Basin is situated immediately north of the Hoyran Basin and is bounded by normal faults. The Karamik swamp is situated north of the basin (Fig. 3).

After the Kaş1kara Basin had been formed (it had initially a N-S orientation), lacustrine sediments started to accumulate during the Mio-Pliocene. The rocks nearby the Kaş1kara Basin can be divided into two major groups: pre-Neogene and post-Neogene (Quaternary). The succession starts, via an unconformity, with the Late Miocene Aşağıkaşıkara Forma-

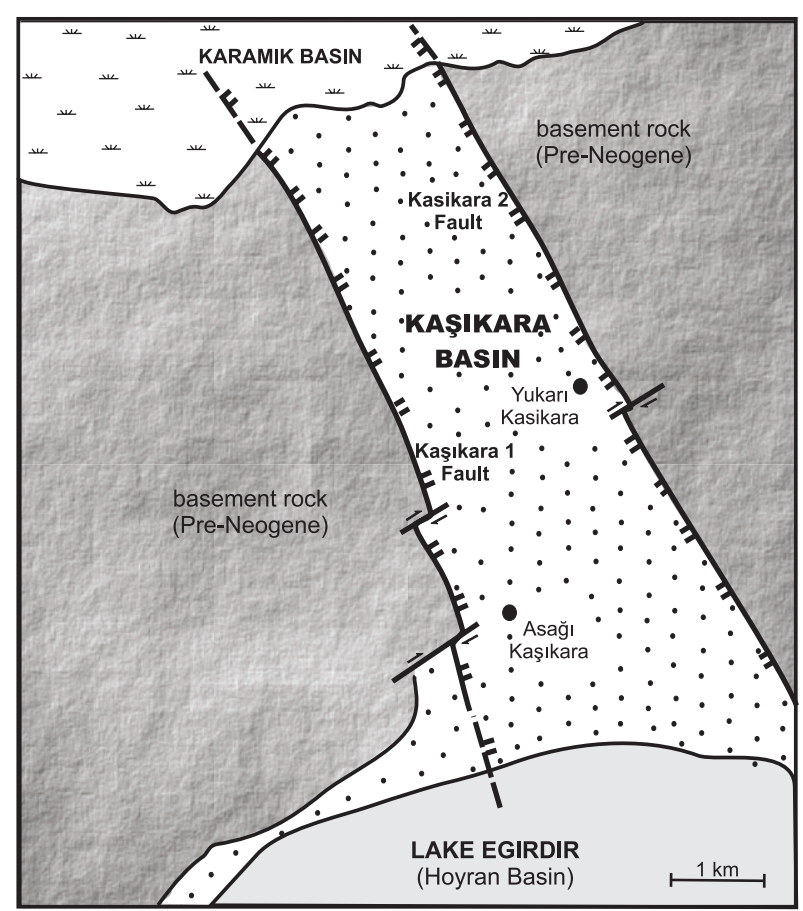

Fig. 3. Simplified geological map of the Kaşıkara Basin (modified after Hançer \& Karaman, 1993).

tion. It is approx. $450 \mathrm{~m}$ thick and the dominant rocks are conglomerates and sandstones. This unit is conformably overlain by the Late Miocene-Pliocene Yukarıkaşıkara Formation, which is $250 \mathrm{~m}$ thick. This formation comprises mainly marls, claystones and mudstones, with an intercalation of 4-10 m of lignite, which represents typical lacustrine sedimentation. The basin thus contains significant, economically exploitable coal and clay reserves.

The western part of the basin deepened, with consequent thickening of clay beds, but the coal beds are thinner here (Kibici et al., 1993). In the uppermost parts of this succession, weakly cemented Quaternary alluvial sediments occur; these are clayey, sandy and pebbly. The presence of widespread lacustrine sediments nearby the Kaşıkara Basin indicates that the shoreline of ancient Lake Egirdir was north of that of the present-day lake.

Along the margins of the Neogene Kaşıkara Basin, normal faults are present; they run from roughly $140^{\circ}$ to $320^{\circ}$. The Kaşıkara 1 fault, which extends over $20 \mathrm{~km}$, occurs on the western side of the basin; it is a dip-slip normal fault. The eastern side of this fault, of which the dip is nearly vertical, is downthrown. Along this fault, basement limestones and Neogene sediments 


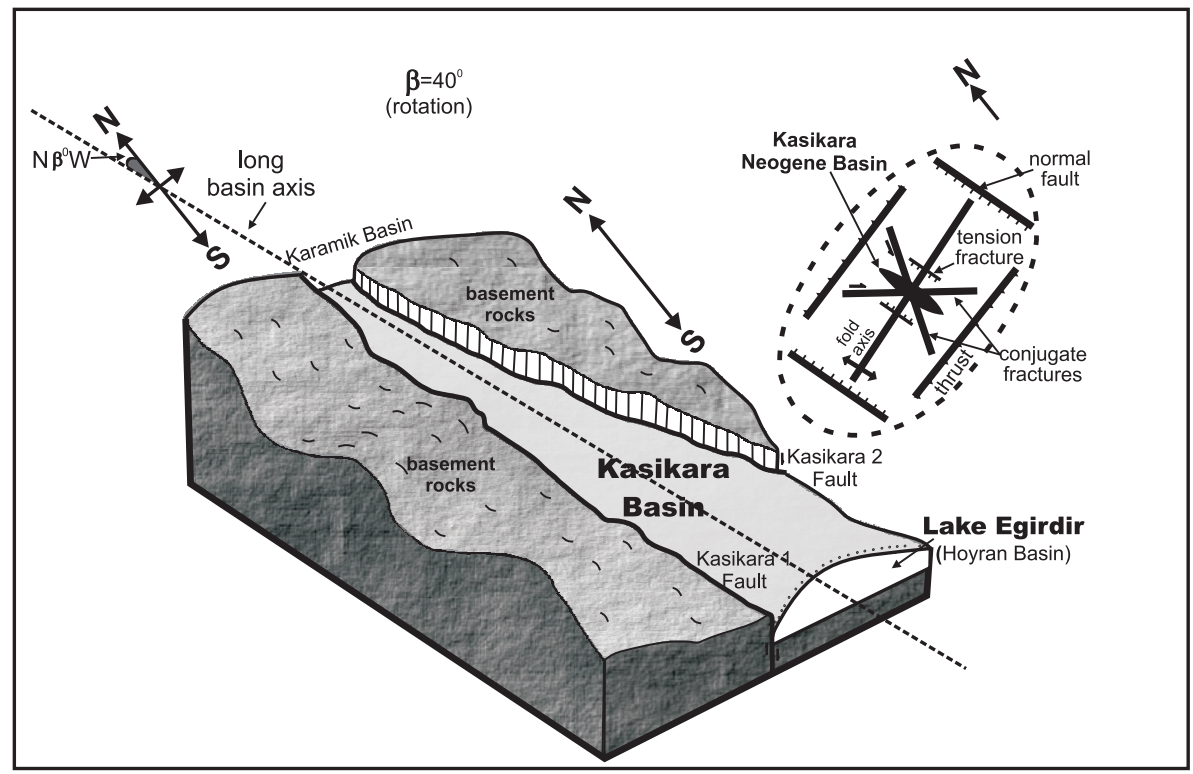

Fig. 4. Schematic model showing the left lateral movement of the Hoyran Basin and the $40^{\circ}$ counterclockwise rotation.

occur at the tectonic contact. The Kaşıkara 2 fault (Figs 4, 5), which is $13 \mathrm{~km}$ long, occurs on the eastern side of the basin. The western side of this fault has been downthrown, and the dip of the fault plane is nearly vertical. Limestones and Neogene lacustrine sediments are present alongside the tectonic contact. There are also many small-scale tectonic structures in the carbonates. For example, the dominant tensional fractures are nearly directed roughly $145^{\circ}-325^{\circ}$ and $155^{\circ}-335^{\circ}$, while conjugate fractures are orientated almost NW. The dominant fold axes and thrusts are, however, orientated almost NE (Fig. 4).

\section{The Kovada Basin}

The graben south of Lake Egirdir is bounded by N-S orientated dip-slip faults (Fig. 6). The width of the graben is about $1.5-2 \mathrm{~km}$. A Mesozoic carbonate succession belonging to the socalled Beydaglari Autochthon is exposed on the western side of Lake Egirdir and the Kovada graben, while autochthonous carbonate rocks of the Akseki-Anamas platform crop out at their eastern side (Koçyiğit, 1984; Poisson, 1984; Şenel, 1984; Poisson et al., 2003).

Yağmurlu \& Şentürk (2005) suggested that the oppositely directed rotations of the eastern and western flanks of the Isparta Angle originated from E-W directed tensional forces in

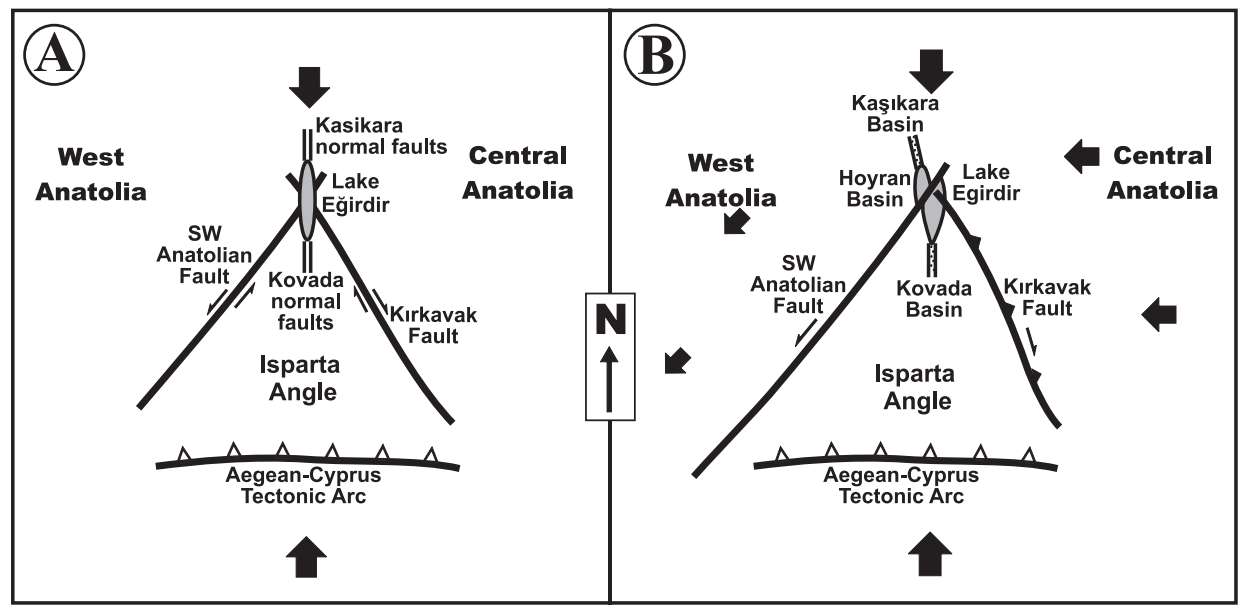

Fig. 5. Tectonic developments.

A - Formation of Lake Eğirdir during the Middle Miocene; B - The left lateral movement of the Hoyran Basin by the South-western Anatolian Fault during the Early Miocene to Holocene. 

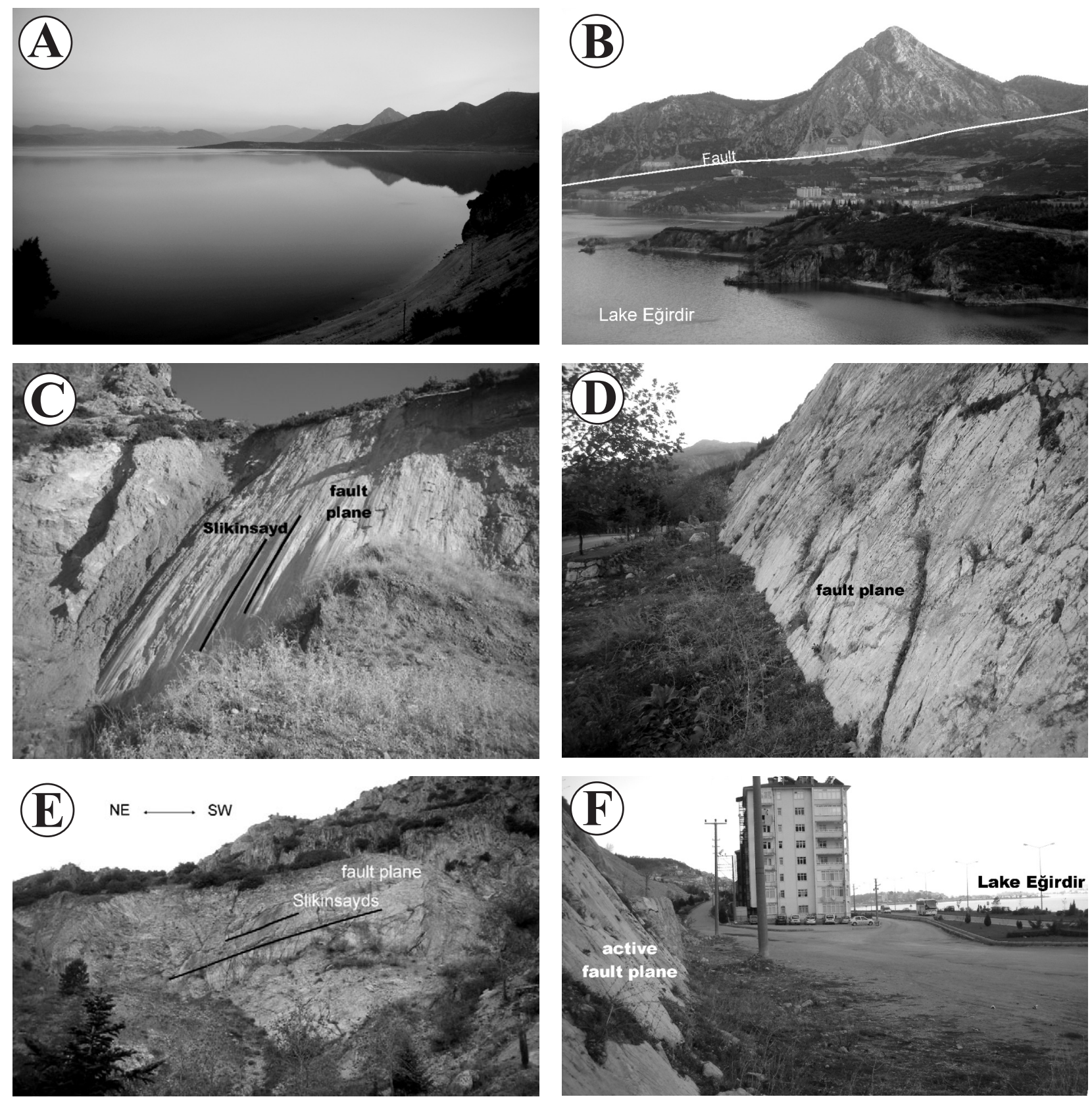

Fig. 6. Tectonics of Lake Eğirdir.

A - General view of Lake Eğirdir; B - General view of the fault edge of Lake Eğirdir; C-D - Dip-slip fault planes at the western edge of Lake Eğirdir; E - Strike-slip fault plane near Eğirdir; F - Fault plane near the lake.

the apex region of the Isparta Angle, and thus gave rise to the N-S oriented Egirdir-Kovada graben. They also indicated that the structure of the Egirdir-Kovada graben narrows from North to South and terminates south of Lake Kovada; in addition, and noted the importance of the fact that the maximum amount of dilation is recorded in the apex region of the Isparta Angle (north of Lake Egirdir).
Few studies concerning the geological, tectonic and sedimentological characteristics in the area of the Kovada graben have been carried out. Yağmurlu \& Karaman (1987) investigated the geological characteristics of the lignite-bearing Neogene basin in the southern part of the Kovada graben area (adjacent to the southern end of Lake Kovada). They suggested that Late Miocene-Pliocene sediments and associated lignite and gypsum were deposited in 
a lacustrine-terrestrial environment that developed in a depression bounded by N-S directed faults, and that these sediments were cut by synsedimentary faults. Furthermore, they reported that, in the southernmost of the internal basins formed in the region, fluvial and lacustrine sediments are present, that lignite horizons of $0.5-2 \mathrm{~m}$ thick occur among claystone and mudstone beds, that playa-lake-type gypsiferous sediments predominate in the (northern) Tilkitaşı Basin, and that N-S directed active growth faults control the orientation and extent of the basin.

\section{Model for the tectonic evolution of Lake Eğirdir}

Lake Egirdir is situated at the northernmost end of the Isparta Angle; in other words, it is located roughly where the South-west Anatolian and Kirkavak faults intersect (Fig. 2). These faults developed during the mid-Miocene in response to N-S compressional forces; where they cross each other, approximately N-S oriented tension fractures and normal faults began to develop. Examples are the Kovada Faults that are located south of Lake Eğirdir and the Kaşıkara Faults that are located north of the Hoyran Basin. In the more advanced stages of tectonic deformation, the areas between these faults subsided and became filled with water, so that Lake Egirdir could develop.

Fault planes and slip surfaces associated with these faults are exposed in many places on the shores of Lake Egirdır. These normal faults, which bound the Kovada graben south of Lake Egirdir and the Kaşıkara graben to its north, are well exposed in the field (Fig. 2) (Karaman, 1989). The South-western Anatolian Fault passes diagonally between the long axes of Lake Egirdir and the Hoyran Basin (Fig. 7).

\section{The tectonic relationship between the Eğirdir and Hoyran Basins}

Lake Eğirdir covers two main basins: the Eğirdir Basin in the South and the Hoyran Basin in the North (Fig. 7). These basins are divided by the South-western Anatolian Fault. The relationship between the basins and the fault is that the Hoyran Basin moved south-westward relative to the Eğirdir Basin by a leftwards lateral slip along the South-western Anatolian Fault (Karaman, 1989). This movement is still continuing. If this will continue for a sufficiently long time, the two basins will become separated from each other, and two individual lakes will result, which might be called 'Lake Eğirdir' and 'Lake Hoyran'.

GPS and palaeomagnetic studies show that central Anatolia moves by left lateral slip

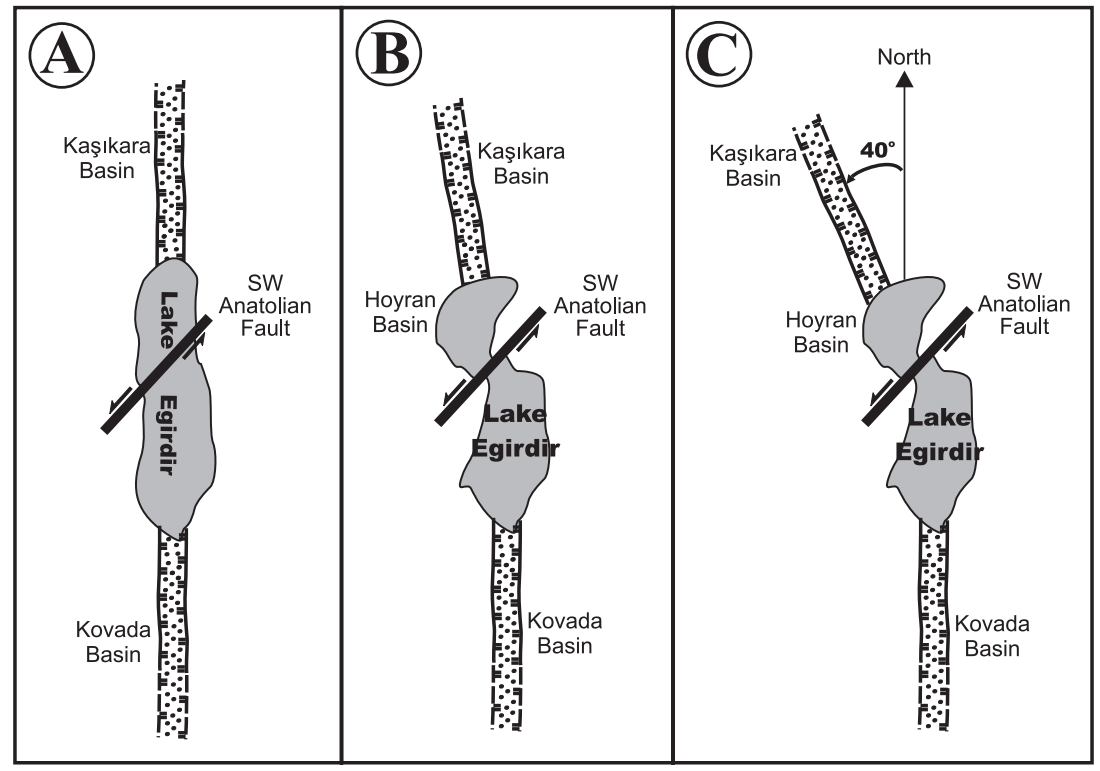

Fig. 7. The long axes of the Hoyran and Kaşıkara Basins was initially directed N-S, but later rotated counterclockwise over $40^{\circ}$. 
along the fault (Erdoğan \& Şahin, 2006; Reilinger et al., 2006). According to the GPS data, the South-western Anatolian Fault has a slip rate of almost $15 \mathrm{~mm}$ per year (Reilinger et al., 1995, 2006; Barka \& Reilinger, 1997; Kahle et al.,1998). On the other hand, Erdoğan \& Şahin (2006) suggested that central Anatolia moves south-westwards relative to Eurasia by 30-35 mm per year. Yağmurlu (1991) suggested that this fault zone (locally named the 'Kumdanl1 Fault') has led to a 2000-m left lateral slip between the villages of Çeleptaş and Kumdanlı near the NE Hoyran Basin since the Pliocene.

\section{The rotation process}

The sinistral strike-slip movement along the South-western Anatolian Fault during the Quaternary resulted in a leftwards directed movement of Lakes Eğirdir and Hoyran relative to one another. Simultaneously, the area northwest of Lake Eğirdir began to rotate counterclockwise. Central Anatolia moves westwards along North Anatolian Fault, but the area of the Isparta Angle, located between central and western Anatolia, is a relatively rigid, stable region. The North Anatolian Fault has a slip rate of $26 \pm 3 \mathrm{~mm}$ per year (Barka et al., 1995), but this motion is slower around of Isparta Angle than farther North. The reason is that the Isparta Angle is probably an important obstacle for westward movement of central Anatolia.
On the other hand, western Anatolia is separated from central Anatolia by the NE orientated South-western Anatolian Fault. Western Anatolia moves south-westwards along this fault zone. North of the Isparta Angle area, central Anatolia moves in the East at a different velocity than it does in the West. Western Anatolia therefore moves south-westwards, thus causing a counterclockwise rotation of approx. $40^{\circ}$ (Fig. 8). Much research has already been devoted to the rotation of this area (e.g. Kissel et al., 1993; Barka et al.,1995; Reilinger et al.,1995; Yağmurlu,1995; Poisson et al., 2003). GPS data indicate that the Anatolian block is undergoing counterclockwise rotation (Reilinger et al.,1995). Palaeomagnetic data support this rotation (Kissel et al., 1993). Along the strike, the amount of slip between the axis of the Kovada and Kaşıkara graben areas and the South-western Anatolian Fault in this area is of the order of $7 \mathrm{~km}$.

In the Late Miocene, the lake area started to become affected by increasing tectonic activity (the so-called neotectonic period). In response to the westward movement of central Anatolia, the Isparta Angle served as a buffer. All along the South-western Anatolian Fault, western Anatolia began to move towards the south-west. While the Hoyran Basin and the Kaşıkara Basin north of this fault moved towards the south-west, because of developing extensional tectonics and warping deformation in western Anatolia, the area north of the
Fig. 8. Simplified map showing the effect of the North Anatolian Fault on the rotation north of Lake Eğirdir.

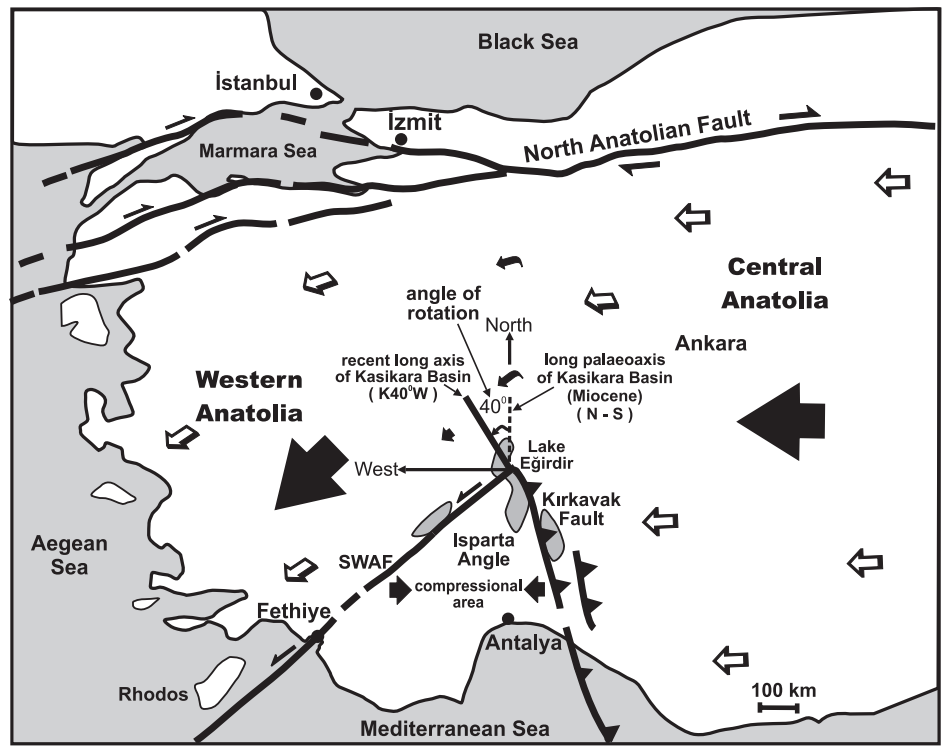


fault began to undergo counterclockwise rotation (Fig. 8). On the basis of outcrops in the area and using geological maps, a block diagram of the Kaşıkara Basin has been prepared, showing that the Kaşıkara graben underwent a $40^{\circ}$ counterclockwise rotation relative to the related Kovada graben to its south.

\section{Conclusions}

It is proposed here that Lake Egirdir has a tectonic origin. Both during and after its development, - which still continues - not only tectonic processes but also other physical factors (such as weathering and erosion) have played important roles. Lakes Burdur and Beysehir are closely related with Lake Eğirdir and developed at the same time. South of Lake Eğirdir, the pyroclastic-fall sediments that occur within the alluvial cones which advance toward the lake, are products of the Pliocene Gölcük (Isparta) volcanism (Kazanc1 \& Karaman, 1988). The above combination of data suggests that the lake basin started to form before the volcanism, that is before the MiddleLate Pliocene.

Lake Eğirdir started to form at the intersection of the NE-SW orientated South-western Anatolian Fault (a result of the increasing N-S stress in the Middle Miocene) with the NNWSSE orientated Kirkavak Fault. Where these faults cross each other, N-S directed tension fractures developed initially, followed by normal faulting during later stages; subsequently, the area between these faults became a graben, so that the are formed a depression which became eventually filled with water, thus forming a lake. The Kaşıkara graben north of Lake Eğirdir and the Kovada graben south of it formed simultaneously. The presence of lignite-bearing Late Miocene-Pliocene lacustrine sediments indicates that these grabens formed before the Late Miocene. The Kaşıkara graben faults, though originally orientated N-S, are currently orientated NW-SE, suggesting that they rotated counterclockwise towards western Anatolia from the South-western Anatolian Fault.
The Kovada graben within the Isparta Angle, situated south of Lake Eğirdir, suggests that it remained stable relative to the other graben and that there was consequently no change in its original N-S direction. The Kaşıkara graben originally developed with a N-S orientation but was forced, because of regional stresses, to rotate approx. $40^{\circ}$ counterclockwise. The present-day orientation of the Kaşıkara Basin, about $140^{\circ}-320^{\circ}$, was obtained via rotation. In addition to the rotation that has occurred along the South-western Anatolian Fault, there has also been sinistral slip. In the northernmost part of the Isparta Angle, the total sinistral slip since the Late Miocene amounts to $7 \mathrm{~km}$.

\section{References}

Alagöz, C.A., 1944. Türkiye'de karst olayları hakkında bir araştırma [The research of karstic events in Turkey]. Türkiye Coğrafya Kurumu Yayın (Ankara) 1, 95 pp.

Ardel, A., 1951. Göller bölgesinde morfolojik müşahadeler [Morphological observations of the lake distric area]. İstanbul Universitesi Coğrafya Enstitüsü Dergisi 2, 1-19.

Alçiçek, M.C, Veen, T.H.J. \& Özkul, M., 2005. Neotectonic development of the Çameli Basin, Southwestern Anatolia, Turkey. [In:] A.H.F. Robertson \& D. Mountrakis (Eds): Tectonic development of the Eastern Mediterranean region. Geological Society, London, Special publications 260, 591-611.

Barka, A. \& Reilinger, R., 1997. Active tectonics of the Eastern Mediterranean region: deduced from GPS, neotectonic and seismicity data. Annali di Geofizica 40, 587-602.

Barka, A., Reilinger, R., Şaroğlu, F. \& Sengör, A.M.C., 1995. The Isparta Angle: its evolution and importance in the tectonics of the Eastern Mediterranean region. International Earth Science Colloqium Aegean Region, Proceedings, 3-17.

Blumenthal, M., 1963. Le système structural du Taurus sud-Anatolien. Mémoires de la Société Géoloque de France 11 (Paul Fellot volume 2), 611-662.

Boray, A., Şaroğlu, F. \& Emre, Ö., 1985. Isparta Büklümünün kuzey kesiminde doğu-batı daralma için veriler [Evidence for East-West shortening north of the Isparta Angle]. Jeoloji Mühendisleri Odası Yayın Organı (Ankara) 23, 9-20.

Bozcu, M., Yağmurlu, F. \& Şentürk, M., 2007. Fethiye-Burdur Fay Zonunun bazı neotektonik ve paleosismolojik özellikleri, GB-Türkiye. [Some geotectonic and paleoseismologic features of Burdur-Fethiye Fault Zone, Turkey]. Jeoloji Mühendisliği Dergisi 66 (Ankara), 12.

Dumont, J.F. \& Kerey, E., 1975. Kırkavak Fayı [The Kırkavak Fault]. Türkiye Jeoloji Kurumu Bülteni (Ankara)18, 59-62. 
Dumont, J.F. \& Kerey, E., 1975. Eğirdir Gölü güneyinin temel jeolojik etüdü [Basic geological study of the southern Lake Eğridir]. Türkiye Jeoloji Kurumu Bülteni (Ankara) 18,169-175.

Erdoğan, S. \& Şahin, M., 2006. Burdur Fethiye fay zonu tektonik hareketlerinin GPS ile belirlenmesi [Determination of the tectonic movements of the BurdurFethiye fault zone using GPS technique). YTÜ Dergisi Cilt (Istanbul) 5 (3), 135-141.

Erol, O., 1969. Tuzgölü havzası jeoloji ve jeomorfolojisi [Geology and geomorphology of the Tuzgölü Basin]. TBTAK (Ankara) Araştırma Raporu TBAG-26, 334 pp.

Erol, O., 1984. Geomorphology and neotectonics of the pluvial lake basins in the Taurus Belt and South Central Anatolia. Geology of the Taurus Belt, (Ankara), 119-124.

Inandik, H., 1965. Türkiye Gölleri [The lakes of Turkey]. İstanbul Üniversitesi Coğrafya Enstitüsü Yayınlar, (Istanbul) 44, $214 \mathrm{pp}$.

Hançer, M., 1991. Kaşıkara (Eğirdir-Isparta) dolayının jeolojisi ve yapisal evrimi. [Geology and structural evolution around Kaşıkara (Eğirdir-Isparta). Ph.D. Thesis, Science Institute of Akdeniz University, Isparta.

Hançer, M. \& Karaman, M.E., 1993. Kaşıkara (EğirdirIsparta) dolayının jeolojisi ve yapısal evrimi [Geology and structural evolution around Kaşıkara (EğirdirIsparta)]. Akdeniz Üniversitesi Isparta Mühendislik Fakültesi Jeoloji Mühendisliği Dergisi (Isparta) 7, 305-315.

Hançer, M. \& Karaman, M.E., 1994. Hoyran Tersiyer (Neojen) havzasının stratigrafisi ve ekonomik potansiyeli [Stratigraphy and economic potential of the Hoyran Tertiary (Neogene) Basin]. Türkiye Jeoloji Kurumu Bülteni (Ankara) 9, 201-208.

Kahle, H.G., Straub, C., Reilinger, R., McClusky, S., King, R., Hurst, K., Veiss, G., Kastens, K. \& Cross, P., 1998. The strain rate field in the eastern Mediterranean region, estimated by repeated GPS measurement. Tectonophysics 294, 237-252.

Karaca, Ö., Karagüzel, R. \& Ertunç, T., 2003. Uzaktan algılama yöntemi kullanılarak Fethiye ve çevresinin jeolojik özelliklerinin belirlenmesi. [Determination of the geological features of Fethiye and surroundings using remote sensing]. Cumhuriyet Universitesi Mühendislik Fakültesi Dergisi A, 20, 52-61.

Karaman, M.E., 1988a. Burdur-Hoyran Fayı [Burdur-Hoyran Fault]. 42.Geological Congress of Turkey, Proceedings, 1-2, Ankara.

Karaman, M.E., 1988b. Ege-Anadolu levha sinırı hakkında bazı yeni görüşler [New aspect of plate boundary between Aegean and Anatolian]. Earth Science 20. Symposium at Hacettepe University, Proceedings, 1-15, Ankara.

Karaman, M.E., 1989. Eğirdir, Kovada, Kaşıkara ve Burdur Geç Senozoyik havzalarının yapısal evrimi ve ekonomik potansiyeli [Structural evolution of Eğirdir, Kovada, Kaşıkara and Burdur Late Cenozoic basins and their economic potential]. Türkiye Jeomorfoloji Bülteni 17, 63-70, Ankara.

Kazanc1, N., 1993. A chronological look at the development of the lake Eğirdir basin. Geological Engineering Journal 42, 50-51, Ankara.

Kazanc1, N., 1995. Eğirdir Göl Çanağının Oluşum Zamanına İlişkin Gözlem II [A chronological look at the development of the lake Eğirdir basin II]. Jeoloji Mühendisliği Dergisi 47, 32-33, Ankara.

Kazanc1, N. \& Karaman, M.E., 1988. Gölcük (Isparta) Pliyosen volkanıklastik istifininin sedimantolojik özellikleri ve depolanma mekanizmaları [Sedimentary characteristics and depositional mechanism of the Gölcük (Isparta) Pliocene volcaniclastics]. Akdeniz Üniversitesi Isparta Mühendislik Fakültesi Jeoloji Mühendisliği Dergisi (Isparta) 3, 4-16.

Kibici, Y., Hançer, M., Karaman, E. \& Aksoy, İ., 1993. Kaşıkara (Isparta) yöresindeki killerin seramik endüstrisinde kullanım olanaklarının araştırılması [Investigation of clays around Kaşıkara (Isparta) and their usage in the ceramics sector]. Abstracts 6th National Clay Symposium of Turkey, İstanbul, 555-565.

Kissel, C., Averbuch, O., Frizon de Lamotte, D., Monod, O. \& Allerton, S., 1993. First paleomagnetic results for a post-Eocene clockwise rotation of the western Taurides thrust belt east of the Isparta re-entrant (SW Turkey). Earth and Planetary Science Letters 117, 1-14.

Koçyiğit, A., 1981. The evolution of Taurus carbonate platform around of Isparta Bend (Western Taurus). Geological Bulletin of Turkey 24, 15-23.

Koçyiğit, A., 1983. Hoyran gölü (Isparta büklümü) dolayının tektoniği [Tectonics of the Lake Hoyran region (Isparta Bend)]. Türkiye Jeoloji Kurumu Bülteni (Ankara) 26, 1-10.

Kozan, A.T., Bozbay, E., Bircan, A., Öğdüm, F. \& Tüfekci, K., 1988. The evolution and development of Burdur Basin. Proceedings 12th Geomorphology Conference of Turkey Ankara), 15-16.

Lahn, I., 1945. Batı Toros göllerinin jeomorfolojisi [Geomorphology of the lakes of the Western Taurus]. Maden Tetkik Arama Enstitüsü Dergisi (Ankara) 34, 387-393.

Lahn, I., 1948. Türkiye gölleri jeolojisi ve jeomorfolojisi hakkında etüd [Study of the geology and geomorphology of Turkish lakes]. Maden Tetkik Arama Enstitüsü Yayım (Ankara) B 12, 87 pp.

Platevoet, B.I, Scaillet, S., Guillou, H., Blamart, D., Nomade, S., Massault, M., Poisson, A., Elitok, Ö., Özgür, N., Yağmurlu, F. \& Yılmaz, K., 2008. Pleistocene eruptive chrolonogy of the Gölcük volcano, Isparta Angle, Turkey. Quaternaire 19, 47-156.

Poisson, A., 1984. The extension of the Ionian trough into southwestern Turkey. [In:] J.F. Dixon \& A.H.F. Robertson (Eds): The geological evolution of the eastern Mediterranean. Geological Society, London. Special Publications 17, 241-250.

Poisson, A., Yağmurlu, F., Bozcu, M. \& Şentürk, M., 2003. New insights on the tectonic setting and evolution around the apex of the Isparta Angle (SW Turkey). Geological Journal 38, 257-282.

Reilinger, R., Tokgöz, R., King, S., McClusky, B., Oral, I., Kınık, O., Lenk, I., Sanlı, A., Barka, A., Prilepin, A., Misın, S., Balassanian, G., Weis, D., Paradissis, A., Tealeb, Y., Melzer, J., \& Mencin, D., 1995. 1994 GPS measurements in Turkey and surroundig areas of the East Mediterranean/Middle East. Abstracts IUGG Conference(Boulder). 
Reilinger, R., McClusky, S., Vernant, P., Lawrence, S., Ergintav, S., Çakmak, R., Özener, H., Kadirov, F., Gliev, I., Stepanyan, R., Nadariya, M., Hahubia, G., Mamoud, S., Sakr, K., ArRajehi, A., Paradissis, D., Al-Aydrus, A., Prilepin, M., Guseva, T., Evren, E., Dmitrotsa, A., Filikov, S.V., Gomez, F., Al-Ghazzi, R. \& Karam, G., 2006. GPS constraints on continental deformation in the Africa-Arabia-Eurasia continental collision zone and implications for the dynamics of plate interactions. Journal of Geophysical Research, Solid Earth 111 (B5), B05411, 52 pp.

Şaroğlu, F., Emre, O. \& Kuşcu, I., 1992. The East Anatolian Fault Zone of Turkey. Annales Tectonicae 6, 99-125.

Şenel, M., 1984. Discussion of the Antalya nappes. [In:] O. Tekeli \& M.C. Göncüoğlu (Eds): Geology of Taurus Belt, 41-51.

Yağmurlu, F., 1991. Yalvaç Yarıkkaya Neojen havzasının stratigrafisi ve depolanma ortamları [Stratigraphy and depositional environments of the Yalvaç-Yarıkkaya Neogene basin, SW Anatolia]. Türkiye Jeoloji Bülteni (Ankara) C 34, 9-19.
Yağmurlu, F., 2000. Burdur Fayının sismotektonik özellikleri [Seismotectonic features of Burdur Fault]. Proceedings Symposium on Seismicity in Western Anatolia (Izmir), 143-151.

Yağmurlu, F. \& Karaman, M.E, 1987. Kovada güneyinde yer alan linyit içerikli dağarası Neojen havzalarının jeolojik özellikleri [Geological features of the lignitebearing inttramontaneous basins (Neogene), south of Kovada Lake, Isparta - Turkey]. Akdeniz Üniversitesi Isparta Mühendislik Fakültesi Jeoloji Mühendisliği Dergisi (Isparta) 3.

Yağmurlu, F. \& Şentürk, M., 2005. Güneybatı Anadolu'nun Güncel Tektonik Yapısı [Recent tectonic structures of SW Anatolia]. Proceedings İTÜ Symposium on the Quaternary (Istanbul), 55-61. 